\title{
Local government financial condition and sustainable development of communities in Nigeria
}

\author{
Obal Usang Edet Usang \\ School Of Accountancy, Universiti Utara Malaysia, Malaysia. \\ Basariah Salim \\ School Of Accountancy, Universiti Utara Malaysia, Malaysia.
}

oScholedge International Journal of Management \& Development (ISSN 2394-3378), Vol.03, Issue 01 (2016) pg11-19. Published by: Scholedge R\&D Center [www.theSCHOLEDGE.org] [Email: sijmd@scholedge.org]

\begin{abstract}
This paper aims at examining the financial condition of local governments in Nigeria and to assess its implications on sustainable development of communities. Secondary data from 122 local governments for a period of three years were utilized in examining the financial conditions of local governments in Nigeria. Findings show that the financial condition of local governments in Nigeria is poor, indicating financial distress. Hence, the deteriorating state of communities as less is available for development. There is need for the development of revenue generating and management strategies by local government administrators in order to ensure sustainable community development.
\end{abstract}

KEYWORDS: Financial condition, Sustainable development, Community development, Local government, Nigeria

\section{INTRODUCTION}

The creation of local government in countries of the world is borne out of decentralization in order to ensure development at the grass root levels. Local governments are better positioned to identify pressing needs of communities and ways of meeting such needs. Also, mobilization and participation of citizens in government is enhanced by the local government [1]. In Nigeria, local government occupies the third tier of government with a mandate to ensure all round development of communities in terms of health, education, sanitation, infrastructure and general wellbeing of the people. In essence, local governments are positioned to bring the government closer to the grass roots for the overall development of the country. This way, citizens are mobilized for participation in leadership and this creates a platform for mentoring potential political administrators [1]. Also, democratic principles are passed on to future leaders through the encouragement of grass root participation. Furthermore, local governments serve as a unifying platform for ethnic diversity and national cohesion through mobilizing and utilizing scarce resources for the wellbeing of communities.

Local governments across the globe are faced with issues that limit their capability to meaningfully improve the wellbeing of communities. According to [3], the world recession of 2008 has severely impacted on local government's ability to meet its obligations to communities. Accordingly, local governments experience financial pressures, increasing services challenges due to rising demand, and insider threats [14, 19, 20, 24]. Reference [7] notes that for most local governments around the globe, fiscal distress is an ongoing struggle. In Nigeria, there is a decline in social services, increased poverty, 
infrastructural decay, inadequate financial resources, mismanagement, and corruption in the local government $[15,18,23]$.

Local Governments in Nigeria statutorily received 20.60 percent of the revenue accruing to the country's federation account plus a 35 percent share of value added tax poll revenue. In addition to this allocation from the federation account, local governments are expected to raise more revenue through taxes, levies, and other economic activities within its jurisdiction as prescribed by the constitution. Since the return of democracy to Nigeria in 1999, massive allocations of financial resources have been channeled to the local governments and close to 16 years after, citizens at the grass roots are still faced with basic issues bothering on development. Basic amenities and services such as health, education, sanitation, and infrastructure are still a far cry as many of these facilities are stretched. More recently, many local governments were unable to pay staff salaries and some still owe staff many months of unpaid salaries. It is interesting to note that these local governments receive monthly allocations from the federation account of the country as outlined above. For example, total revenue received by Nigerian local governments from the federation account for the years 2010 to 2012 amounted to 1,359.9 billion naira, 1,636.2 billion naira and 1,644.3 billion naira respectively [9]. This shows the enormous resources available to the local governments for massive development of communities and well-being of communities. However, available evidence suggest otherwise as poverty in the rural communities is severe by up to 80 percent, limited services like health care, education, and sanitation to communities, and widespread decay in infrastructural facilities [15, 23]. Thus, development of communities is limited and general apathy on the ability of local governments to deliver on their mandate now pervades. A few studies have sparingly examined financial condition of local governments in Nigeria [16, 22] but none has comprehensively studied the financial conditions of local governments in Nigeria. In view of the above, this paper examines the financial condition of local governments in Nigeria and its implication on the sustainable development of communities. Specifically, four financial condition ratios were examined and the sustainability implications on community development were discussed. The remaining part of the paper includes a review of related literature on financial conditions of local government and sustainability; method adopted for the study; results and discussion; and conclusion of the study.

\section{LITERATURE REVIEW}

\subsection{FINANCIAL CONDITION}

Financial condition is associated with similar terms like fiscal health, financial health, financial performance, fiscal stability, and fiscal strength. The term connotes an organization's ability to provide future services without interruptions [11]. It also portrays the ability of an organization to meet its obligations to creditors and stakeholders as and when due [26]. Generally, financial condition is examined using indicators such as budgetary, cash, service, and long-term solvency [27, 25, 28]. Also, financial condition is defined variously according to the author's focus. For example, [17] defined financial condition as the ability of government to meet its short and long-term obligations as the fall due without compromising current quality of services. Others examined the construct as changes in net assets over a period of time $[2,10]$. However, the common feature is that of examining whether an organization's financial condition is improving or not with the view to assessing the impact on its ability to meet stakeholder's demands.

Empirical studies on financial condition of local government have used several indicators. For example, self income ratios, financial performance index, ratio of percentage change in net assets to total assets, and fiscal balance $[8,12,17]$. Similarly, this study utilized four ratios: fiscal balance ratio, financial performance index, self income ratio, and budget solvency ratio in examining the financial condition of local governments in Nigeria. Fiscal balance ratio (FSB) shows the extent to which revenues exceed cost. A surplus here shows the local government's ability to contribute to infrastructural development while a deficit indicates otherwise. The financial performance index (FPI), 
also known as self sufficiency ratio indicates how much internally generated revenue cover total expenditures. The higher the index, the higher the financial performance and the less reliance on federally allocated revenue. Self income ratio (SIR) shows how much of total revenue is made up of internally generated revenue. The higher the ratio, the better the financial condition of the local government. Budget solvency ratio (BSR) shows the extent to which total revenues from all sources cover total expenditures. Accordingly, the higher the BSR, the better the financial condition of the local government.

\subsection{FACTORS INFLUENCING FINANCIAL CONDITION IN THE LOCAL GOVERNMENT}

Several factors have been outlined as determinants of the financial condition in the local government. Reference [7] developed a framework of factors influencing local government's financial condition. These factors are grouped into structural or fixed factors, organizational factors, and hybrid factors. Structural factors relate to factors which require a long time before changes can be made and are important when strategies to improve financial conditions are being developed. Indicators of fixed factors include: size of local government, socioeconomic status of the population, and allocated revenue from central government.

Organizational factors relate to the internal managerial capabilities of the local government. According to [7], indicators of organizational factors include: transparency, performance evaluation, and managerial abilities of the management local government. Organizational factor indicators can be influenced and improved by local government administrators for better use of resources. For example, transparency requires that organizations should be honest and open in their operations. It also connotes accountability and eliminating all avenues for corruption and mismanagement of resources. Performance evaluation is important also in enabling the local government evaluate policies and programmes and their impact on communities with a view to improving areas of poor performance. All these can only be made possible where managerial commitment and capabilities are effectively utilized. Reference [12] found significant relationship between quality of management and performance of local governments in Brazil.

Hybrid factors refer to the relationship between local government and state or central government. According to [7], this relationship is not sufficiently institutionalized as responsibilities are not adequately delineated which causes a lack of coordination between governments. In Nigeria, Local governments are perceived as an appendage of the state and central governments and this has hindered local initiative and focus on the part of local government administrators [4, 27]. However, it is in the best interest of the state and central governments to resolve conflicts in order to deliver value to citizens.

\subsection{FINANCIAL CONDITION AND SUSTAINABILITY}

The financial condition of an organization influences the long-term survival of the organization. Financial resource is acknowledged as an important resource for organizational expansion and satisfaction of stakeholder's demands [5]. In view of this, the financial condition of an organization provides a clue as to the sustainability of the organization in terms of survival and ability to meet expectations of stakeholders who depend on her. Thus, crisis occurs when an organization is unable to raise enough revenue to cover its expenditures. In the long run, the survival of the organization is threatened and leads to loss in stakeholder's confidence. Similarly, the financial condition of local governments is an important element in the sustainable development of communities. Sustainable development cannot occur where local governments are unable to raise enough revenue to meet the needs of the communities being served. 
Sustainable development refers to development that meets present needs without compromising future generation's ability to develop and meet their own needs [6]. Sustainable development also bothers on the need to manage economic, social and environmental resources in a way that future generations can also benefit. Sustainability in Community development means continued improvement in current needs of communities while guaranteeing future community development improvements. In order for this to happen, the financial condition of local governments should be seen to improve, instead of deteriorating. A healthy financial condition of local governments more than guarantees that future community developments would be undertaken and sustained and this can be achieved through strategies that maximize generation of own revenue. In a study of local governments in Ogun state, [22] asserts that local government rarely generated up to 10 percent of their total revenues from internal sources. It therefore show the over reliance of local governments on the federation account. With the plummeting price of crude in the international market, Nigeria's fortunes have dwindled and this spells more financial distress for local governments. Hence, there is need for strategies to explore areas where internally generated revenue can be harnessed.

\section{METHOD}

Data for this study were from published financial statements of Nigerian local government councils. Nigeria has a total of 774 local government councils spread across the six geopolitical zones of the country. The sample size was based on availability of published financial data for the years 2011 to 2012. Those local governments with incomplete reports for the years under study were excluded. Thus, the study is based on 122 local government councils in Nigeria. In other to derive the ratios for examining financial condition of the sampled local governments, data on internally generated revenue, total revenue, and total expenditure were extracted from their published financial reports. Internally generated revenue represents revenue derived from the councils engagement in business activities and from local taxes and rates collected. Total revenue represents internally generated revenue and statutory allocations from the federation account while total expenditure captured both recurrent and capital expenditures of the local governments. The ratios include: fiscal balance ratio, which represents the proportion of fiscal surplus (deficit) to total revenue: financial management index, given as a proportion of internally generated revenue to total expenditure; self income ratio, which represents the proportion of internally generated revenue to total revenue; and budget solvency ratio, which represents the proportion of total revenue to total expenditure. Thus, the ratios were calculated for each year and thereafter, an average for the three year period was obtained. The discussions on financial condition of local governments in this study were based on the average ratios obtained.

\section{RESULTS AND DISCUSSION}

From the descriptive statistics of the financial condition of the 122 local governments studied, the fiscal balance ratio ranged from a minimum of -.320 to a maximum of .269 , with a mean of .050 (SD =.107). Furthermore, the financial performance index ranged from .001 to .109, with a mean of .009 (SD = .017). The self income ratio ranged from a minimum of .001 to .246, with an average of .029 (SD = .047). Also, the budget solvency ratio ranged from a minimum of .822 to a maximum of 1.944, with a mean of $1.090(S D=.161)$. The descriptive statistics for the financial condition of the local governments studied is presented on Table 1.

Table 1

Descriptive Statistics for financial condition

\begin{tabular}{lllllll}
\hline Rs & LGs & Min & Max & Mean & SD & Var \\
\hline FSB & 122 & -.320 & .269 & .050 & .107 & .012 \\
FMI & 122 & .001 & .109 & .009 & .017 & .000 \\
SIR & 122 & .001 & .246 & .029 & .047 & .002
\end{tabular}




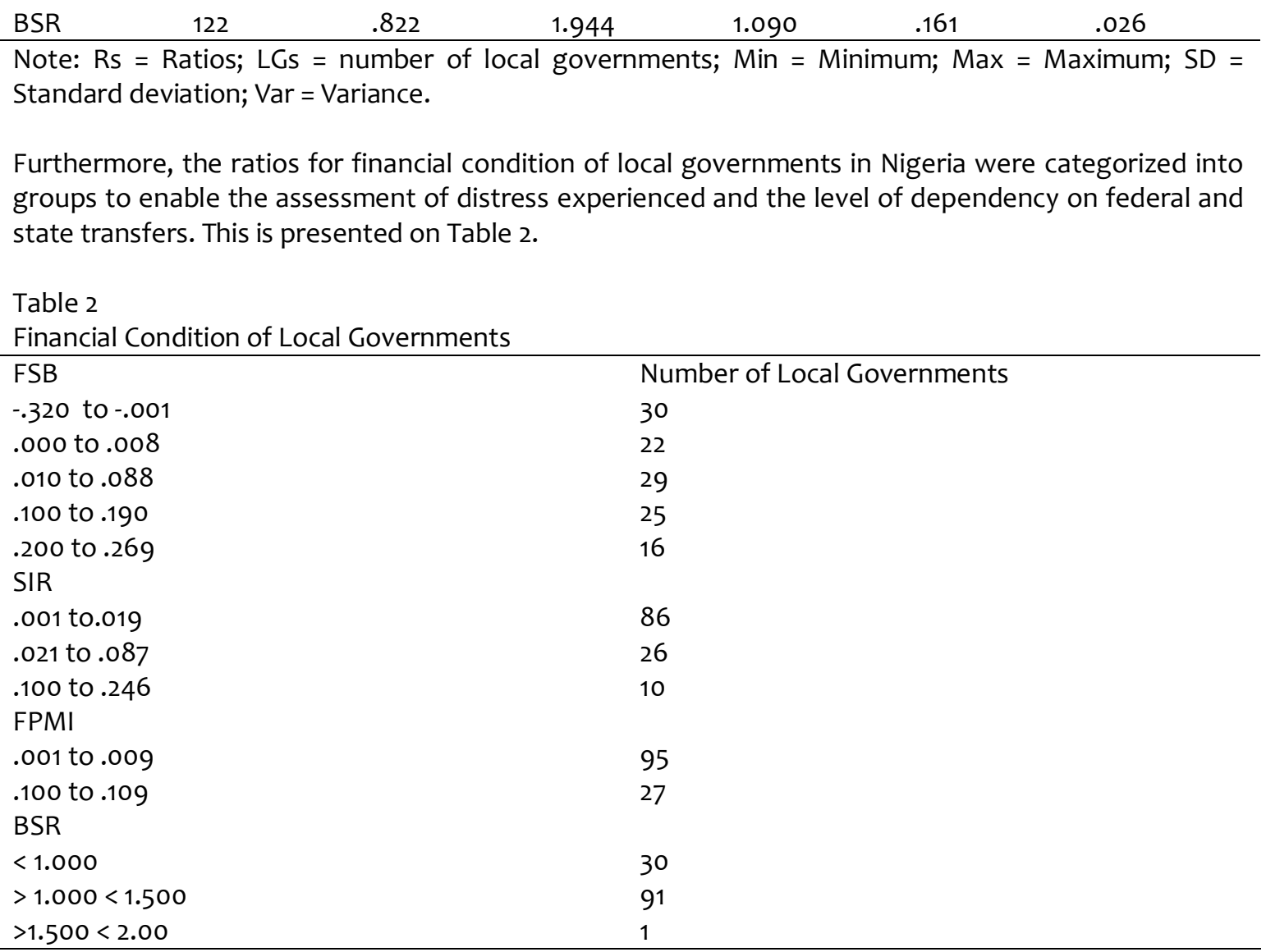

From Table 2, the fiscal balance ratio (FSB) indicates how much revenues exceed costs. A surplus portrays the local government's ability to undertake and contribute to infrastructural development of the community. Thirty local governments incurred deficits while 92 local governments marginally had surplus. These surpluses show a weak contribution to development of communities. The financial performance management index (FPMI) showed the lack of self sufficiency of the 122 local governments as the ratio is far less than one. Reference [12] suggest that as the FPMI approaches zero, the more the reliance of the local government on transfers from higher government authorities. Thus, none of the local governments showed good financial performance. The self income ratio (SIR) indicates poor financial condition of the local governments in terms of their ability to generate sufficient own revenue. According to [7], the closer the SIR to one, the better the financial condition of the local government and the less dependence on federal and state government for allocations to funding. Consequently, none of the local governments studied had a ratio close to one, which shows the poor financial condition of the local government. Furthermore, the budget solvency ratio (BSR) indicates the extent to which total revenue from all sources more than cover total expenditures. It is the ability of government to generate adequate revenues to cover expenditures without incurring deficits [13]. According to [28], the higher the BSR, the better the financial condition of the organization. A total of 92 local governments were able to marginally cover their expenditures for the period while 30 local governments were unable to do so. On the whole, the financial condition of these local governments can be classified as poor for the period studied. Given this scenario, no meaningful and sustainable development can take place in the communities being served unless drastic measures are undertaken to improve revenue generation. Besides from the sustainability point of view, deficits incurred are similar to spending future resources. This also implies that present 
consumption is being funded by the future, thus jeopardizing future community development of generations yet unborn.

\section{CONCLUSION}

The paper examined the financial conditions of local governments in Nigeria and sustainability of communities. Available data indicates poor financial condition of the local governments in Nigeria. Although many factors influence the financial condition of local governments, the ability to generate and manage self income remains an important task for sustainable development of communities. With the present financial conditions, no meaningful development can take place and rural poverty would rise further. Strategies for improvement in internally generated revenue of local governments should be explored as this has been underutilized over the years because of excessive dependence on federally allocated revenue.

\section{REFERENCES}

[1] Achimugu, H., Stephen, M. R., and Agboni, U. J. (2013) 'Local government service delivery in Nigeria : an empirical comparison of government efforts and the people's expectations', Mediterranean Journal of Social Sciences, Vol. 4 No.6, pp.335-346

http://dx.doi.org/10.5901/mjss.2013.v4n6p335

[2] Aikins, S. K. (2011) 'An examination of government internal audits' role in improving financial performance', Public Finance and Management, Vol. 11 No.4, pp.306-337

[3] Ammons, D. N., Smith, K. W., and Stenberg, C. W. (2012) 'The future of local government: will current stresses bring major, permanent changes?', State and Local Government Review, Vol. 44 Suppl. 1, pp. 64S-75S http://dx.doi.org/10.1177/0160323X12454143

[4] Asaju, K. (2010) 'Local government autonomy in Nigeria: Politics and challenges of the 1999 Constitution', International Journal of Advanced Legal Sudies and Governance, Vol. 1 No. 1, pp.98-113

[5] Barney, J. (1991) 'Firm resources and sustained competitive advantage', Journal of Management, Vol. 17 No. 1, pp.99-120

http://dx.doi.org/10.1177/014920639101700108

[6] Brundtland, G. (1987) 'Our Common Future', Oxford University Press, Oxford.

[7] Carmeli, A. (2008) 'The fiscal distress of local governments in Israel: sources and coping strategies', 
Administration \& Society, Vol. 39 No.8, pp. 984-1007

http://dx.doi.org/10.1177/0095399707309358

[8] Carmeli, A., \& Tishler, A. (2004). The relationships between intangible organizational elements and organizational performance. Strategic Management Journal, Vol. 25 No.13, pp.1257-1278

http://dx.doi.org/10.1002/smj.428

[9] Central Bank of Nigeria. (2012). Fiscal policy and government finance [online]. http://www.cenbank.org/out/2013/RSD/2012 Annual Report_Chapter 5_Fiscal Policy and Government Finance.pdf. (Assessed 14 July 2015)

[10] Chaney, B. A., Mead, D. M., and Schermann, K. R. (2002) 'The new governmental financial reporting model : what it means for ...', The Journal of Government Financial Management, Vol. 51 No.1, pp.26-31

[11] Epstein, B. M. J., and Mcfarlan, F. W. (2011) 'Measuring the efficiency and effectiveness of a nonprofit's performance', Strategic Finance, Vol. 93 No.4, pp. 27-34

[12] Gomes, R. C., Alfinito, S., and Albuquerque, P. H. M. (2013) 'Analyzing local government financial performance : evidence from Brazilian municipalities 2005 - 2008', RAC Rio de Janeiro, 17(6) [online] www.anpad.org.br/rac (Assessed 20 July 2015).

[13] Groves, S. M., \& Valente, M. G. (1994) 'Evaluating financial condition: A handbook for local government', International County/City Management Association, Washington, D.C.

[14] Hilvert, C., \& Swindell, D. (2013) 'Collaborative service delivery: what every local government manager should know', State and Local Government Review, Vol. 45 No. 4, pp. 240-254 http://dx.doi.org/10.1177/0160323X13513908

[15] IFAD. (2012) Enabling poor rural people to overcome poverty in Nigeria. [online] https://www.yumpu.com/en/document/view/7897513/enabling-poor-rural-people-to-overcomepoverty-in-nigeria (Assessed 2 August 2015) 
[16] Khalil, S., and Adelabu, S. A. (2012) 'Fiscal planning and local government administration in Nigeria : the quest for sustainable rural development', African Journal of Business Management, Vol. 6 No.9, pp. 3482-3489

[17] Kioko, S. N. (2013) 'Reporting on the financial condition of the states: 2002-2010', Journal of Public Budgeting, Accounting \& Financial Management, Vol. 25 No.1, pp.165-198

[18] Lawal, T., and Oladunjoye, A. (2010) 'Local government, corruption and democracy in Nigeria', Journal of Sustainable Development in Africa, Vol. 12 No.5, pp. 227-235

[19] Levine, H., and Scorsone, E. (2011) 'The great recession's institutional change in the public employment relationship: implications for state and local governments', State and Local Government Review, Vol. 43 No.3, pp. 208-214 http://dx.doi.org/10.1177/0160323X11428811

[20] Luby, M. J. (2014) 'Not all refinancings are created Equal: a framework for assessing state and local government debt refinancing measures' State and Local Government Review, Vol. 46 No.1, pp. $52-62$ http://dx.doi.org/10.1177/0160323X13520434

[21] Maher, C. S., and Deller, S. C. (2011) 'Measuring municipal fiscal condition: do objective measures of fiscal health relate to subjective measures?', Journal of Public Budgeting, Accounting \& Financial Management, Vol. 23 No.3, pp. 427-450

[22] Olusola, O. (2011) 'Boosting internally generated revenue of local governments in Ogun State, Nigeria (A study of selected local governments in Ogun State) ', European Journal of Humanities and Social Sciences, Vol. 8 No.1, pp.336-348.

[23] Oviasuyi, P. O., Idada, W., and Isiraojie, L. (2010) 'Constraints of local government administration in Nigeria', Journal of Social Science, Vol. 24 No.2, pp.81-86

[24] Perlman, B. J. (2014) 'Refinancing state and local debt: Decreased current costs or decreased 
future flexibility?' State and Local Government Review, Vol. 46 No.1, pp.46-51

http://dx.doi.org/10.1177/0160323X14521218

[25] Rivenbark, W. C., and Roenigk, D. J. (2011) 'Implementation of financial condition analysis in local government', Public Administrative Quarterly, Vol. 35 No.2, pp. 241-267

[26] Shah, P. (2010) 'Evaluation of financial soundness through bivariate accounting based performance measurement', Drishtikan: A Management Journal, Vol. 1 No.2, pp. 352-369.

[27] Usang, O. U. E., and Salim, B. (2015), 'A conceptual perspective of internal audit quality and local government performance in Nigeria' in ICAS 2015: Proceedings of the International Conference on Accounting Studies, Institute for Strategic and Sustainable Accounting Development (ISSAD), Kedah, Malaysia, pp. 1-8.

[28] Wang, X. D., Dennis, L., and Tu, Y. Sen. (2007) 'Measuring financial Condition : a study of U.S. states', Public Budgeting \& Finance, Vol. 27 No.2, pp.1-21.

http://dx.doi.org/10.1111/j.1540-5850.2007.00872.x 